\title{
An exploratory investigation on the influence of practical experience towards shaping future early childhood teachers' practice in the arts
}

\author{
Susanne Garvis \\ Griffith University
}

\begin{abstract}
ACCORDING TOTHE NATIONAL Education and the Arts Statement (Ministerial Council for Education, Early Childhood Development and Youth Affairs, 2007), all children and young people should have a high-quality arts education. The statement also supports the notion that arts experience can be the first meaningful point of engagement in the education system for students. To achieve quality arts education, teachers require a high level of skill and training (Andrews, 2004). This suggests teachers require significant training to help develop a strong sense of perceived capability towards teaching in the area of arts education.

This study explores the beliefs of early childhood teachers in their first three years of teaching. Focusing on self-efficacy beliefs, this study used Bandura's (1997) model of self-regulated learning as a base from which to consider sources of an early childhood teacher's sense of agency related to teaching the arts. Findings suggest teachers develop beliefs about arts education during practical experience that shape attitudes towards teaching arts in the early years. These findings have important messages for improving arts education.
\end{abstract}

\section{Introduction}

Early childhood teachers gain skills for teaching the arts in teacher education.

Without sufficient teacher training in music and the arts, teachers can develop negative perceptions about their own confidence and competence (Bartel, Cameron, Wiggins \& Wiggins, 2004). The teaching of the arts is also influenced by life experience, personal experience and perceptions of confidence (Robinson, 2001).

Recent national inquiries suggest the standard of arts teaching within Australia is inadequate (DEST, 2005; DEST, 2008). In 2005, the National Review of School Music Education (DEST, 2005) raised a number of questions in relation to the training generalist teachers receive in music. The review highlighted a decline in the number of hours given for generalist primary pre-service education courses (Pascoe et al., 2005), suggesting preservice teachers did not have adequate time to enhance their teaching skills in music. Similar findings were made in First We See: The National Review of Visual Education, highlighting the decline of visual art education in teacher training (DEST, 2008). Both reviews highlight the absence of status and support for music and visual arts in most teacher education programs for primary educators, calling for improvement in pre-service teacher training and ongoing professional learning. Further investigation of beliefs towards teaching the arts is therefore necessary in teacher education and during professional development.

In this paper, we focus on the factors that affect quality arts education through the lens of self-efficacy. We examine how self-efficacy information is likely to influence thearts education practices of beginning teachers. In particular, we look at the influence of supervising teachers.

\section{Theoretical connections}

Self-efficacy is defined as 'beliefs in one's capabilities to organise and execute the courses of action required to produce given attainments' (Bandura, 1997, p. 3). The construct of teacher self-efficacy is grounded within selfefficacy theory, emphasising that people can exercise influence over what they do (Bandura, 2006). A teacher's beliefs system about the arts will therefore determine the quality of arts education in the classroom. Self-efficacy develops over time and through personal and vicarious 
experiences (Bandura, 1997). Beliefs are created through decisions influencing actions, attitudes, emotions and thoughts. Thus, self-efficacy acts as a motivational construct, determining the actual amount of effort an individual will bring to the task of teaching as they assess their ability to perform the task successfully (TschannenMoran and Woolfolk Hoy, 2001).

Teacher self-efficacy has been related to greater commitment to teaching (Coladarci, 1992), greater levels of planning and organisation (Allinder, 1994), decreased teacher burnout (Brouwers \& Tomic, 2003), a wider variety of teaching material with the desire to search for a new teaching formulae, and the use of innovative teaching methods (Ghaith \& Yaghi, 1997; Wertheim \& Leyser, 2002). Woolfolk Hoy (in Shaughnessy, 2004) suggests that, if teachers seek to help students increase their academic and selfregulatory self-efficacy, they should first attend to the sources underlying their own teacher beliefs.

Teacher self-efficacy beliefs are influenced by four sources, including (1) mastery experiences; (2) vicarious experience (modelling); (3) verbal persuasion; and (4) emotional arousal (Bandura, 1997). These may happen simultaneously or in isolation. Mastery is considered the strongest source (Bandura, 1997; Tschannen-Moran \& Woolfolk Hoy, 2001). When an experience (or performance) is perceived as successful, self-efficacy is raised. When the performance is perceived a failure, self-efficacy beliefs are lowered. The level of emotional arousal (either excitement or anxiety), adds to the feelings of mastering a task. Vicarious experiences are associated with the modelling of a task. If the observer can identify the skills with the modeller, teacher self-efficacy can be enhanced. The final source, verbal persuasion, consists of discussions around the task being performed. The potency of verbal persuasion depends on the credibility, trustworthiness and expertise of the persuader (Bandura, 1997).

Within arts education, research has explored the influence of specific knowledge and skills to teacher self-efficacy. Previous research by Temmerman (1997) and Bartel and Cameron (2002) has shown that a perceived lack of competency to teach the knowledge and skills required in music was a significant internal factor affecting teachers' perceptions of their musical ability. Furthermore, in a comparison between one New Zealand and one Canadian generalist teacher, self-efficacy towards music, levels of competency and self-efficacy clearly influenced curriculum (Bartel et al., 2004), with few teachers able to show an understanding of students' musical thinking. These two teachers were also unable to make judgements 'about the value or importance of the consequences of an action for the arts' (Bartel et al., 2004, p. 88). These results suggest teacher self-efficacy strongly influences the ways arts education is taught in classrooms.

\section{Focus of study}

This study focuses on the following two questions:

1. What sources of arts education self-efficacy information do beginning teachers receive during practical experience?

2. How are these sources of self-efficacy information likely to influence their own arts education practices?

\section{The participants}

For purposes of this study, beginning teachers (defined as teachers in the first three years of their career since graduating from a teacher education institution) working in early childhood education from both private and public schools in Queensland, Australia were invited to complete a questionnaire on teacher selfefficacy in relation to arts education. Ultimately, 21 out of 60 questionnaires were returned from participants, a response rate of 35 per cent.

Participants answered a 'call for participants email' sent though the Beginning Teachers Association to all early childhood beginning teachers. They were current members of this organisation.

Participants were assured that the survey was anonymous. They were sent an online survey that could be completed outside of school hours.

\section{Research methods}

The survey consisted of 10 open questions designed to elicit descriptions of beginning teachers' experiences with arts education, as part of the professional experience component of their teacher education program.During this time, the then pre-service teachers were supervised by a teacher with at least three years' experience.

Results were analysed using content analysis,a research technique for making replicable and valid inferences from texts to the context of their use' (Krippendorff, 2004, p.18). An adapted version of Cavana, Delahaye and Sekaran's (2003, p.171) 15 stages of content analysiswas used as a guide to identify key themes and meanings. Coding for 'manifest content' (Wallen\& Fraenkel, 2001) was used, acknowledging what was directly written in the online survey.

\section{Results of the content analysis}

In general, the participants described negative experiences that had occurred during the professional experience component of their pre-service teacher education program. Overall, these experiences were shaped by either supervising teacher practices (a form of modelling), or supervising teacher feedback (verbal persuasion). The 
participants also talked about the tensions they saw between the arts and other subjects, showing links to vicarious experience and emotional arousal (contextual influences). Tensions were shown by supervising teachers, with the curriculum being overcrowded and a greater focus placed on the teaching of literacy and numeracy. This appeared to create negative teacher selfefficacy beliefs for teachers about the arts in school.

Three main categories emerged from the content analysis:

1. supervising teacher practice (vicarious experience),

2. supervising teacher feedback(verbal persuasion), and

3. the profile of arts as a subject experienced by the participant (vicarious experience). Each category is discussed below.

\section{Supervising teacher practice}

The first category supported the proposed vicarious experience as a source of efficacy (Bandura, 1997). Vicarious experiences (also known as modelling) allowed participants to personally experience arts education teaching practices. Experiences described by participants showed a clear lack of mastery experience in supervising teachers. This suggests that supervising teachers did not model suitable arts education practice.

One beginning early childhood teacher described a negative experience with a supervising teacher in a kindergarten. She felt disheartened that arts practices were not being modelled within this particular early childhood education setting:

One of the saddest moments of my practical teaching was when I was studying my Grad Diploma and I was at a well-regarded kindergarten. I was there for two weeks and basically the same activities were set out. I questioned the director as to why some children were not getting involved in the art activities and she told me that 'this lot are not very creative!' This went against all my beliefs about early childhood education and I felt very sorry for those children (Beginning Teacher, B).

Another beginning teacher also commented on the lack of quality arts education she saw in practice during her professional experience:

I did little arts work on practical experience. If I did it was art and the activities were always related to the unit I was teaching at the time. Very restricted though (Beginning Teacher, A).

Unfortunately, lack of arts education appeared common amongst the beginning early childhood teachers who completed the survey. Thirteen teachers (62\%) wrote they had not seen any form of arts education in the early years during their professional experience:
I never saw it used on any teaching prac. (Beginning Teacher, C).

Many of my prac teachers did not do the arts (Beginning Teacher, J).

These findings suggest the participants did not experience positive modelling during teacher practical experience that would lead to positive teacher selfefficacy for the arts. Without adequate opportunities for positive vicarious experiences, pre-service teachers may need to draw on other sources of efficacy to develop perceived capabilities towards teaching the arts.

\section{Supervising teacher feedback}

Some beginning early childhood teachers described hearing negative comments (negative verbal persuasion) from their supervising teacher regarding the teaching of arts education. The participants who described these experiences felt that the supervising teacher did not value the arts, which influenced the beginning teachers' values in relation to the teaching of the arts in early childhood classrooms.

One beginning teacher described a negative experience with a Year $1 / 2$ classroom teacher:

On my first prac at a public state school I was involved in art groups that consisted of all of things that I had avoided in my work in early childhood centres. Stencilled outlines of horses that children had to collage over, bubble blowing painting... where was the freedom of expression in that? When doing a maths lesson in subtraction for a Year 1 and 2 composite class I sang 10 green bottles with the class. The children sang along happily but my supervising teacher told me to keep the noise down so as not to disturb the children next door (Beginning Teacher, F).

Another beginning early childhood teacher also described the negativity from a supervising teacher when she tried to teach the arts to students:

My teacher thought the arts weren't as important. When I started teaching them, I got in trouble (Beginning Teacher, I).

Verbal persuasion appeared to influence the selfefficacy of the participants during their practical experience. The verbal feedback given by supervising teachers appeared to shape current understandings about the arts in the early years classroom.

\section{The profile of arts as a subject}

Typically, early childhood educators do not have formal training in the arts (Eisner, 1988; Eisner \& Day, 2004) in pre-service education programs, but are encouraged to 'integrate' arts into the core curricular areas.Beginning early childhood teachers wrote about the place of arts in 
the curriculum while on their professional experience. These teachers suggested that this lack of exposure to the arts as part of the curriculum impacted upon their current beliefs and may potentially have an impact on their future practice.

One participant suggested that some teachers deintellectualised the arts, making it a 'fun' subject:

Many teachers allow students to develop this 'bludge' mentality by not valuing the arts themselves. It is a difficult battle to reform students' opinions (Beginning Teacher, L).

One beginning teacher also wrote about poor teacher training leading to inadequate teaching of the arts in schools. Subsequently, she suggested generalist teachers teach only certain subject areas:

I don't think teachers that have been around a long time see the benefit of it or have the training or ability to implement it. They just teach reading, writing and maths (Beginning Teacher, M).

The portrayal of the arts would lead the supervising teacher to model the teaching of the arts with certain characteristics. The pre-service teacher would see this negative modelling and may also start to develop negative beliefs about the arts.

\section{Summary}

What is clear from comments from the 21 participants is that there is a negative arts profile in some early childhood classrooms in Queensland, Australia. These experiences were based on professional experience in classrooms under the guidance of supervising teachers during preservice teacher education programs. It is unclear to what extent these negative experiences have shaped the participants' current teaching practice as beginning early childhood teachers. While some of the participants suggested it influenced their teaching of the arts as a beginning teacher, without observation of the teacher it is hard to provide an empirical recount. What is known is that participants remembered the negativity towards the arts while on practical experience.

\section{Final thoughts}

The previous results provide an interesting starting point for analysis in the investigation of beginning early childhood teachers' beliefs on their pre-service teacher education. It appears that supervising teacher practices, supervising teacher feedback, and the profile of the arts as a subject contribute to a teacher's selfefficacy. The previous discussion, which focuses on beginning early childhood teachers' perceptions of their arts education experiences in their pre-service teacher training, provides an insight into sources of self-efficacy information about the teaching of arts education.
Without positive experiences created through Bandura's (1997) proposed sources of efficacy (mastery experience, vicarious experience, verbal persuasion and emotional arousal), beginning early childhood teachers may feel they have little capability when teaching the arts in their own classroom. In the long term, these experiences may contribute to lower teacher self-efficacy for the arts, creating a cyclical problem of failure for arts education in early childhood.

From this study, a major concern of teacher-educators appears to be helping pre-service teachers understand the importance of arts education in the early years and to critique experiences while on practical experience. Based on the data collected, it appears participants remember the negative events with arts education. This could suggest that, since these events were remembered, they are held as possible sources of efficacy for the beginning teacher.

From this research, two issues are raised: (1) teacher education and (2) professional development. First, how do universities control how supervising teachers demonstrate quality arts education practices? If supervising teachers' self-efficacy for the arts is low, how can they be equipped to model and critique suitable arts practice in the classroom? Their lack of teaching in the arts will then affect the beginning teacher they are supervising, possibly creating a continual cycle of failure. As Bandura (1997) suggests, giving teachers a sense of efficacy is critical if they are going to even attempt the task.

The second issue raised is ensuring professional development opportunities in arts education for early childhood teachers. To improve teacher self-efficacy for the arts in early childhood greater support is needed in the form of professional development for early childhood teachers working in schools and early childhood centres. Through ongoing professional development, these teachers can begin to value the arts in the decisions about implementing curriculum.

In conclusion, current practices in arts education courses within early childhood teacher education must be reviewed if teachers are expected to learn skills they can use in the classroom. Closer links must be made with supervising teachers. This study has also raised questions about future research for arts education in the early years. For example, what are the current influences on teacher self-efficacy for early childhood teachers in schools? Can professional development and community involvement help improve arts education in schools? Can a generalist teacher have strong teacher self-efficacy for all key learning areas? Such research would provide teachereducators, schools and policy-makers with evidence of crucial periods where beginning early childhood teachers require greater support. This would allow teacher selfefficacy for arts education to be supported throughout the beginning phase of teaching. 


\section{References}

Allinder, R. M. (1994). The relationship between efficacy and the instructional practices of special education teachers and consultants.Teacher Education and Special Education, 17, 86-95.

Andrews, B.W. (2004). Curriculum renewal through policy evelopment in arts education. Research Studies in Music Education, 23, 76-93.

Bandura, A. (1997). Self-efficacy: The exercise of control. New York: Freeman.

Bandura, A. (2006). Adolescent development from an agentic perspective. In F. Pajares \& T. Urdan (Eds.).Self-efficacy beliefs of adolescents, (Vol. 5., pp. 1-43). Greenwich, CT: Information Age Publishing.

Bartel, L. R.,\& Cameron, L. M. (2002). Self-efficacy in teachers teaching music. Proceedings of the American Educational Research Association (AERA) Annual Conference, New Orleans.

Bartel, L., Cameron, L., Wiggins, J., \& Wiggins, R. (2004). Implications of generalist teachers' self-efficacy related to music. In P.M. Shand (Ed), Music education entering the 21st century (pp. 85-90). Nedlands, AU: International Society for Music Education.

Brouwers, A., \& Tomic, W. (2003). A longitudinal study of teacher burnout and perceived self-efficacy in classroom management. Teaching and Teacher Education, 16, 239-253.

Cavana, R.Y., Delahaye, B.L., \& Sekaran, U. (2001). Applied business research: Qualitative and quantitative methods. Brisbane, Queensland: John Wiley and Sons.

Coladarci, T. (1992). Teachers' sense of efficacy and commitment to teaching. Journal of Experimental Education, 60, 323-337.

Department of Education, Science and Training (DEST) and Centre for Learning, Change and Development (2005). National Review of School Music Education: Augmenting the diminished. Retrieved 10 March, 2009, from http://www. dest.gov.au/sectors/school_education/publications_resources/ profiles/school_music_education.htm.

Department of Education, Science and Training (DEST) (2008). First We See: National Review of Visual Education. Retrieved 28 April, 2010, from http://www.dest.gov.au/sectors/school_ education/publications_resources/profiles/First_We_See_The_ National_Review_Visual_Education.htm.

Eisner, E. W. (1988). The role of discipline-based art education in America's schools. Los Angeles: Getty Center for Education in the Arts.

Eisner, E.W., \& Day, M. (Eds) (2004). Handbook of research and policy in art education. Canada: University of British Columbia.

Ghaith, G., \&Yaghi, H. (1997). Relationships among experience, teacher efficacy and attitudes towards the implementation of instructional innovation. Teaching and Teacher Education, 13(4), 451-458.

Ministerial Council on Education, Training and Youth Affairs (MCETYA) (Federal) and Cultural Ministers' Council (2007). National Statement on Education and the Arts. Canberra: Department of Communication, Information Technology and the Arts.

Krippendorff, K. (2004). Content analysis: An introduction to its methodology (2nd edn). Beverly Hills, CA: Sage.
Pascoe, R., Leong, S., MacCallum, J., Mackinlay, E., Marsh, K., Smith, B., et al. (2005). National review of school music education: Augmenting the diminished. Retrieved 15 March, 2009, from www.dest.gov.au/sectors/school_education/ publications_resourcces/profiles/school_music_education.htm.

Robinson, K. (2001). Out of our minds: Learning to be creative. Oxford: Capstone Publishing Limited.

Shaughnessy, M.F. (2004). An interview with Anita Woolfolk: The educational psychology of teacher efficacy. Educational Psychology Review, 16(2), 153-176.

Temmerman, N. (1997). An investigation of undergraduate music education curriculum content in primary teacher education programmes in Australia. International Journal of Music Education, 30, 26-34.

Tschannen-Moran, M.,\& Woolfolk Hoy, A.W. (2001). Teacher efficacy: Capturing an elusive construct. Teaching and Teacher Education, 17(7), 783-805.

Wallen, N., \& Fraenkel, J. (2001). Educational research: A guide to the process (2nd edn). Mahwah, NJ: Lawrence Erlbaum.

Wertheim, C.,\& Leyser, Y. (2002). Efficacy beliefs, background variables, and differentiated instruction of Israeli prospective teachers. The Journal of Educational Research, 68(2), 202-248. 